\title{
РОЗКРИТТЯ НЕФІНАНСОВОЇ ІНФОРМАЦІЇ В ЗВІТНОСТІ ПІДПРИЕМСТВ МАЛОГО БІЗНЕСУ
}

\author{
Татьяна Гоголь, Вадим Колоток
}

\section{РАСКРЫТИЕ НЕФИНАНСОВОЙ ИНФОРМАЦИИ В ОТЧЕТНОСТИ ПРЕДПРИЯТИЙ МАЛОГО БИЗНЕСА}

\section{Tatiana Gogol, Vadym Kolotok \\ DISCLOSURE OF NON-FINANCIAL INFORMATION FOR REPORTING PURPOSES OF SMALL BUSINESS ENTERPRISES}

У статті обгрунтовано важливість відображення нефінансової інформачії для зовнішніх та внутрішніх користувачів звітності малого бізнесу та доведено необхідність розкриття інформації щзодо дотримання прав людини та трудових відносин, антикорупиійної діяльності, взаємодї̈ з органами місцевого самоврядування, екології тощо. Проаналізовано стандарти обліку, щуо регламентують формування різних видів нефінансової звітності та показники, щзо додатково розкриваються в таких звітах з метою підтвердження аналітичної інформації. Розглянуто види нефінансової звітності, щуо складають украӥнські підприємства, та обтрунтовано склад показників, щзо дочільно розкривати малим підприємствам, які вже подають звітність такого виду або планують зробити ие в майбутньому.

Ключові слова: нефінансова звітність; інформація; користувачі; стандарти; управління; малий бізнес.

Табл.: 2. Бібл.: 19

В статье обоснована важность отображения нефинансовой информации для внешних и внутренних пользователей отчетности малого бизнеса и доказана необходимость раскрытия информации о соблюдении прав человека и трудовых отношений, антикоррупиионной деятельности, взаимодействия с органами местного самоуправления, экологии и др. Проанализированы стандарты учета, регламентирующих формирование различных видов нефинансовой отчетности и показатели, которые дополнительно раскрываются в таких отчетах с иелью подтверждения аналитической информации. Рассмотрены виды нефинансовой отчетности, что составляют украинские предприятия и обоснованно состав показателей, что целесообразно раскрывать малым предприятиям, которые уже подают отчетность такого вида, или планируют сделать это в будущем.

Ключевые слова: нефинансовая отчетность; информация; пользователи; стандартьл; управление; мальй бизнес.

Табл.: 2. Библ.: 19.

The article substantiates the importance of displaying non-financial information to external and internal users of small business reporting and also proves the need to disclose information on human rights and labor relations, anti-corruption activities, interaction with local governments, environmental issues and so on. Accounting standards governing the formation of various types of non-financial statements have been analyzed, together with the indicators which are further disclosed in such reports in order to confirm analytical information. The types of non-financial reporting constituting Ukrainian enterprises have been considered, the composition of indicators appropriate for disclosing to small business enterprises, which are already submitting reports or planning to do so in the future, have been justified.

Keywords: information; management; small business; non-financial reporting.

Table: 1. References: 19.

JEL Classification: M40

Постановка проблеми. Забезпечення своєчасною та якісною інформацією управлінський персонал є важливим інструментом ефективного управління різними сферами діяльності суб’єктів господарювання, що потребує формування як фінансової, так і не фінансової інформації в межах системи управління. Формування нефінансової інформації та іiї розкриття в звітності формує широке коло об’єктивної та корисної інформації про діяльність суб' єктів господарювання, що дозволить краще інформувати користувачів про всі аспекти діяльності підприємства, зокрема і про нефінансові сфери його діяльності. Для стабільного розвитку підприємств малого бізнесу, збільшення прозорості його роботи, менеджмент малих підприємств, контрагенти, споживачі, працівники та інші користувачі мають отримувати не тільки інформацію про стан активів, зобов’язань, власного капіталу та результати діяльності суб'єкта господарювання, а і про інші аспекти діяльності підприємства (соціальна відповідальність, антикорупційна діяльність, взаємодія з місцевими громадами, екологічні питання та ін.), що зумовлює актуальність теми цього дослідження.

(c) Гоголь Т. А., Колоток В. О., 2020 
ФІНАНСОВІ РЕСУРСИ: ПРОБЛЕМИ ФОРМУВАННЯ ТА ВИКОРИСТАННЯ

Аналіз публікацій. Питання розкриття нефінансової інформації в нефінансових звітах на підприємствах, зокрема малого бізнесу досліджували багато науковців, зокрема А. Косич [11], М. Проданчук [5], В. Воробей [12], І. Журовська [12], В. Шевчук [17] та інші.

Виділення недосліджених частин загальної проблеми. Недостатність грунтовних досліджень щодо виокремлення нефінансових показників діяльності у звітності та ії інформаційного наповнення зумовлює вивчення питання необхідності й доцільності формування нефінансової звітності та її інформаційну складову для сектору малого бізнесу.

Мета статті. Метою статті $є$ дослідження питання розкриття нефінансової інформації в звітності підприємств малого бізнесу, що дозволяє виділити такі завдання:

- обгрунтувати необхідність складання нефінансової звітності на підприємствах малого бізнесу;

- виокремити форми нефінансової звітності на підприємствах малого бізнесу;

- виділити види нефінансової інформації для ії розкриття в нефінансовій звітності на малих підприємствах.

Виклад основного матеріалу. Інформація в управлінні підприємствами, зокрема малими, відіграє важливу роль, оскільки на ії основі приймаються управлінські рішення. Інформацію, якою користується менеджер при прийнятті рішень, можна умовно поділити на фінансову та нефінансову. Фінансова інформація забезпечує управлінський персонал малого підприємства та зовнішніх користувачів інформацією про фінансовий стан та фінансові результати діяльності, фінансову стабільність, ліквідність, платоспроможність, ділову активність підприємства. Нефінансова інформація має на меті розкривати більш детально та всеосяжно ті аспекти діяльності підприємства, які не можна описати за допомогою фінансових показників. Вона матиме описовий і аналітичний характер та дозволяє отримати більше об'єктивної, корисної і якісної інформації таким користувачам, як кредитори та інвестори, покупці й замовники, працівники, постачальники та інші. До такої інформації можна віднести інформацію про конкурентоспроможність підприємства, його продуктивність, екологічні дані, відомості про просування товарів чи послуг на ринках, соціальну підтримку персоналу тощо.

Отримати нефінансову інформацію можна як із внутрішніх, так і зовнішніх джерел, а саме: дані з внутрішніх інформаційних систем компанії, ЗМІ, соціальної мережі, відгуки клієнтів, спеціалізовані огляди та дослідження окремих ринків, звіти й огляди від незалежних зовнішніх експертів, опитування клієнтів, спостереження, тестування тощо [6]. Така інформація може подаватися в нефінансовій звітності, що зумовлює формування довіри до підприємства з боку різних груп впливу; підвищення прозорості підприємства; зміцнення ділових відносин та сприяння розширення ринків збуту й доступу до фінансових ресурсів, а також формування іміджу відповідального роботодавця серед молодих спеціалістів [4], що є важливим в умовах забезпечення розвитку підприємств малого бізнесу.

3 метою формування та розширення інформаційного кола щодо господарської діяльності формуються передумови для розкриття нефінансової інформації в показниках звітності підприємств різних форм власності та розмірів, що зумовило удосконалення нормативно-правової бази з регулювання даного питання, а саме внесено зміни до Закону України «Про бухгалтерський облік та фінансову звітність» (у жовтні 2017 року), якими передбачено складання звіту про управління [10] та розроблено методичні рекомендації, які визначають зміст, порядок складання та розкриття інформації в такій звітності [11].

А. Косич та Я. Яковенко зазначають, що «і фінансова, і нефінансова звітність розрахована на однакові групи користувачів, однак інформація нефінансової звітності здатна задовольнити інформаційні запити більшої аудиторії, враховуючи тих, хто не володіє достатніми знаннями для тлумачення економічних показників. Водночас варто пам'ятати, що нефінансовий звіт щодо фінансового є другорядним та лише доповнює його» [5] та 
ФІНАНСОВІ РЕСУРСИ: ПРОБЛЕМИ ФОРМУВАННЯ ТА ВИКОРИСТАННЯ

дозволяє управлінському персоналу малого бізнесу та зовнішнім користувачам приймати управлінські рішення та контролювати їх виконання стосовно діяльності підприємства, яка пов'язана з такими сферами, як економічне становище підприємства, протидія корупції, дотримання прав працівників та споживачів, екологічні питання тощо.

Вважаємо, що складання нефінансової звітності на підприємствах малого бізнесу $є$ доцільним та обгрунтованим, однак повинно враховувати розміри малого підприємства, інформаційні потреби користувачів нефінансової інформації та ресурсні можливості управлінського персоналу. Особливістю організації діяльності на підприємствах малого бізнесу є обмеження фінансових і трудових ресурсів та інформаційне забезпечення управлінського персоналу, що зумовлює дослідження питання обсягів та видів нефінансової інформації та форми ії розкриття в показниках нефінансової звітності.

Це питання розглядали багато науковців. М. Проданчук пропонує малим підприємствам складати нефінансову звітність у вигляді довільного документа, де описувати свою соціальну та екологічну діяльність [12]. В. Воробей та I. Журовська вважають, що Звіт про прогрес - зручна форма нефінансового звіту для малого та середнього бізнесу [1]. Згідно з даними сайта United Nations Global Compact [18], близько 15 українських компаній малого та середнього бізнесу, які працюють у різних галузях економіки, складають звіт про прогрес. Цей звіт $\epsilon$ стандартизованою формою, яка регламентується United Nations Global Compact. Також, як зазначає А. Кальчук, у світі нефінансова звітність може розкриватися у вигляді комплексних звітів [4]. О. Сидоренко пропонує деталізувати інформацію щодо видів діяльності (за видами продукції (товарів, робіт, послуг); способами отримання доходу (способами розповсюдження продукції, товарів, робіт, послуг); характером виробничого процесу; характерними для цієї діяльності ризиками; категорією покупців за господарськими та географічними сегментами у фінансовій звітності [14]. Таким чином, формування нефінансової звітності підприємствами малого бізнесу може здійснюватися в довільній формі, у формі комплексних звітів, або в стандартизованій формі (визначеними міжнародними стандартами).

Вважаємо, що управління на підприємствах малого бізнесу має самостійно обирати форму складання нефінансової звітності, зважаючи на цілі діяльності, які планується досягти, розкриваючи нефінансову інформацію, інформаційні потреби користувачів та ресурси малого підприємства.

Розглянемо, яка інформація може розкриватися в окремих видах нефінансової звітності на підприємствах малого бізнесу. Для цього проаналізуємо найпоширеніші форми нефінансових звітів, які пропонуються міжнародними стандартами: звіт про прогрес; звіт зі сталого розвитку за стандартами GRI і звіт з управління (табл. 1).

Таблиця 1

\section{Порівняння форм нефінансової звітності}

\begin{tabular}{|c|c|c|c|}
\hline Вид звіту & Структура звіту & Розкриття інформації & Регламентація \\
\hline 1 & 2 & 3 & 4 \\
\hline $\begin{array}{c}\text { Звіт } \\
\text { про прогрес }\end{array}$ & $\begin{array}{l}\text { Мінімально обов’язково в звіті по- } \\
\text { винна бути: заяви про підтримку } \\
\text { Глобального договору керівництвом } \\
\text { компанії, опис конкретних дій, } \\
\text { спрямованих на виконання десяти } \\
\text { принципів, закладених договором та } \\
\text { показники результативності }\end{array}$ & $\begin{array}{l}\text { Розкриття інформації про } \\
\text { права людини, трудові } \\
\text { відносини, захист довкіл- } \\
\text { ля та протидію корупції }\end{array}$ & $\begin{array}{l}\text { Складання звіту рег- } \\
\text { ламентується } \\
\text { United Nations Global } \\
\text { Compact }\end{array}$ \\
\hline $\begin{array}{l}\text { Звіт зі стало- } \\
\text { го розвитку } \\
\text { за стандар- } \\
\text { тами GRI }\end{array}$ & Структура звіту не визначена & $\begin{array}{l}\text { Розкриття інформації про } \\
\text { економічні (економічна } \\
\text { ефективність, наявність на } \\
\text { ринку, антикорупційна } \\
\text { діяльність), екологічні та } \\
\text { соціальні питання }\end{array}$ & $\begin{array}{l}\text { Стандартизація здійс- } \\
\text { нюється GPI. Розроб- } \\
\text { лено види стандартів: } \\
\text { загальні, економічні, } \\
\text { екологічні, соціальні. } \\
\text { Всього } 37 \text { стандартів } \\
\end{array}$ \\
\hline
\end{tabular}


Закінчення табл. 1

\begin{tabular}{|c|c|c|c|}
\hline & & & \\
\hline $\begin{array}{c}\text { Звіт } \\
\text { з управління }\end{array}$ & Структура звіту не визначена & $\begin{array}{l}\text { Містить достовірний } \\
\text { огляд розвитку, діяльності } \\
\text { та стану підприємства, а } \\
\text { також опис основних ри- } \\
\text { зиків і невизначеностей, } \\
\text { якими воно має справу }\end{array}$ & $\begin{array}{l}\text { Директива 2013/34/СС } \\
\text { Свропейського парла- } \\
\text { менту та ради Свро- } \\
\text { пейського Союзу від } \\
26 \text { червня } 2013 \text { року }\end{array}$ \\
\hline
\end{tabular}

Джерело: складено авторами на основі $[15 ; 17 ; 19]$.

Як бачимо, існують різні форми нефінансової звітності та види інформації, що розкривається в таких звітах. У звіті про прогрес розкривається інформація щодо дотримання прав людини та трудові відносини з працівниками, екологічні питання та існування корупційної складової щодо діяльності підприємства. У звіті про сталий розвиток пропонується розкривати інформацію про економічні, екологічні та соціальні аспекти діяльності підприємства, зокрема і про антикорупційну діяльність. У звіті з управління формується інформація про стан та розвиток підприємства, а також про ризики та невизначеність діяльності на сучасному етапі його розвитку.

До того ж, як зазначає В. Онищенко та К. Гнедіна, звіт про управління є супровідним до фінансової звітності підприємства та доповнює, але не повторює ії. Доповнює він іiї тією інформацією про підприємство, яку неможливо отримати з фінансової звітності, але вона $є$ необхідною для інвестора та суспільства для розуміння результатів діяльності підприємства, зокрема й соціальних, його перспектив розвитку та ризиків і невизначеностей, в умовах яких воно функціонує [2; 9].

Директивою 2014/95/EU визначено, що підприємства, які зобов'язані складати нефінансову звітність, повинні відображати питання екологічної проблеми: деталі поточного та передбачуваного впливу діяльності підприємства на навколишнє середовище; питання охорони здоров'я та безпеки; використання відновлюваної та/або невідновлюваної енергії; викиди парникових газів; використання води та забруднення повітря. Щодо соціальних питань та питань, пов'язаних із відносинами з працівниками, наводиться інформація щодо дій, які вживаються для забезпечення гендерної рівності, виконання фундаментальних конвенцій Міжнародної організації праці, умов праці, соціального діалогу, повагу до прав на інформування та консультацію працівників, повагу до профспілкових прав, охорони праці та безпеки праці та діалог з місцевими громадами та/або заходи, що вживаються для забезпечення захисту та розвитку громади. Інформація в нефінансовій звітності щодо прав людини, антикорупційної діяльності та хабарництва може включати інформацію про запобігання зловживанням правами людини та/або про інструменти для боротьби з корупцією та хабарництвом [16].

Розглянемо більш детально основні інформаційні потреби в нефінансовій інформації зовнішніх і внутрішніх користувачів малих підприємстві в умовах обмеження фінансових, інформаційних та ресурсних можливостей таких підприємств.

Працівники будь-якого підприємства, у процесі виконання своїх повноважень, повинні не порушувати права людини. Це стосується і персоналу підприємств малого бізнесу. Зокрема, працівники малого підприємства мають ставитися етично до своїх клієнтів, дотримуватися конфіденційності при роботі з їхніми персональними даними, не порушувати їхні інші права, визначені Конституцією України та міжнародними нормами. Тому в нефінансовій звітності суб'єкти малого бізнесу можуть розкривати інформацію про заходи, що вживаються для захисту прав людей, зокрема клієнтів та працівників підприємства, що дозволить управлінню малого бізнесу краще реагувати на можливі порушення з боку працівників прав людини та вживати заходів щодо недопущення такого в майбутньому. 
ФІНАНСОВІ РЕСУРСИ: ПРОБЛЕМИ ФОРМУВАННЯ ТА ВИКОРИСТАННЯ

Діяльність малих підприємств зазвичай здійснюється на місцевому чи регіональному рівні, тому їхня діяльність $є$ основним джерелом наповнення місцевих бюджетів, зокрема в невеликих об'єднаних громадах, містах, селищах та селах, що впливає на розвиток економіки місцевих громад. Малі підприємства тісно співпрацюють 3 органами місцевого самоврядування та можуть надавати, фінансову підтримку садочкам, школам та іншим бюджетним установам. Тому вважаємо, що малі підприємства також можуть розкривати інформацію в нефінансовій звітності про взаємодію з місцевою владою та населенням громад.

Під час своєї діяльності малі підприємства мають використовувати власні трудові ресурси так, щоб отримувати найбільшу продуктивність. Водночас потрібно, щоб працівникам було забезпечено належні умови праці, виплачувалася достойна заробітна плата, робота поєднувалася з відпочинком та було забезпечено гнучкість у роботі збереження балансу між особистим та професійним життям. Досягти останнього можна надаючи відпустки на навчання та організовувати дистанційну роботу для окремих категорій працівників (хто має маленьких дітей або обмежені фізичні можливості). Також необхідно вдосконалювати навички та вміння, отримувати додатковий досвід для роботи, що вимагає організації перепідготовки та підвищення кваліфікації для своїх працівників. Тому в нефінансовій звітності малий бізнес може розкривати інформацію пов'язану з трудовими відносинами: умови праці та можливості, щодо їх покращення; час перебування працівників на роботі; періодичність отримування відпусток; заходи, які вживаються для підвищення професійного досвіду працівників.

Діяльність суб'єктів господарювання різних галузей і сфер діяльності та розмірів тісно пов'язана $з$ державними та бюджетними органами (видача дозволів та ліцензій, господарська діяльність 3 державними та бюджетними установами та ін.), що може впливати на антикорупційну діяльність підприємств малого бізнесу. Звісно, на малих підприємствах найменше корупції, в порівнянні з великими та середніми, однак такі випадки можуть мати місце. Тому в нефінансовій звітності суб'єктів малого підприємництва може розкриватися інформація про проблеми, антикорупційні заходи та результати щодо протидії корупції.

Будь-яка діяльність суб'єктів господарювання впливає на навколишнє середовище, що вимагає від підприємств різних форм та сфер діяльності піклуватися про збереження навколишнього середовища. Тому в нефінансовій звітності доцільно розкривати інформацію про вжиті заходи щодо збереження навколишнього середовища або зменшення негативного впливу на нього. На основі цієї інформації управлінський персонал зможе приймати рішення, спрямовані на зменшення забруднення навколишнього середовища, яке відбувається в процесі діяльності та здійснювати інші заходи, щодо забезпечення покращення екологічної ситуації в регіоні.

Отже, вважаємо, що підприємства малого бізнесу можуть включати до нефінансової звітності інформацію щодо забезпечення прав людей, відносин із працівниками, співпрацю з органами місцевого самоврядування та жителями громад, дані про антикорупційну діяльність та збереження навколишнього середовища.

У нефінансовій звітності малих підприємств, крім аналітичного тексту, може також надаватися підтверджувальна інформація у вигляді різноманітних показників, що додатково розкриває та обгрунтовує наведені нефінансові показники в такій звітності. Для прикладу наведемо, які показники включають до своєї звітності українські підприємства («Нексія ДК», ТОВ «АГРОТЕХСОЮЗ», АТ «Пласке», ДП «НАЕК «ЕНЕРГОАТОМ») (табл. 2). 
ФІНАНСОВІ РЕСУРСИ: ПРОБЛЕМИ ФОРМУВАННЯ ТА ВИКОРИСТАННЯ

Таблиця 2

Показники, які розкриваються в нефінансовій звітності украӥнських підприємств

\begin{tabular}{|c|c|}
\hline Види показників & Показники ефективності \\
\hline Екологічні питання & $\begin{array}{l}\text { - } \text { використання підприємством води, електроенергї та енергоресурсів; } \\
\text { - обсяг утилізації відходів; } \\
\text { - } \text { кількість співробітників, які скористалися послугами санітарно- } \\
\text { курортного лікування; } \\
\text { - кількість висаджених зелених насаджень (дерев, кущів тощо); } \\
\text { - } \text { рівень переходу на енергозберігаючі лампи }\end{array}$ \\
\hline Соціальні та трудові аспекти & $\begin{array}{l}\text { - чисельність працівників; } \\
\text { - } \text { розподіл працівників за стажем роботи; } \\
\text { - витрати на заходи та засоби з охорони праці; } \\
\text { - обсяг матеріальної винагороди персоналу; } \\
\text { - використання відпусток персоналом; } \\
\text { - обсяг надання матеріальної допомоги персоналу; } \\
\text { - інвестиції в підготовку персоналу; } \\
\text { - загальна кількість годин навчань персоналу; } \\
\text { - витрати на благодійність; } \\
\text { - витрати на медичне страхування }\end{array}$ \\
\hline $\begin{array}{l}\text { Взаємодія з місцевими } \\
\text { громадами }\end{array}$ & $\begin{array}{l}\text { - кількість новорічних подарунків подарованих дітям громадах; } \\
\text { - обсяг допомоги навчальним та соціальним закладам; } \\
\text { - } \text { кількість студентів, які пройшли практику на базі підприємства; } \\
\text { - } \text { кількість дітей, що побували на екскурсії на підприємстві по програмі } \\
\text { профорієнтації; } \\
\text { - } \quad \text { витрати на утримання об'єктів соціальної інфраструктури }\end{array}$ \\
\hline Повага до прав людини & $\begin{array}{l}\text { - розподіл працівників на керуючих посадах за статтю; } \\
\text { - вікова структура працівників }\end{array}$ \\
\hline Антикорупційна діяльність & - участь у круглих столах (семінарах) з питань протидії корупції \\
\hline
\end{tabular}

Джерело: розроблено авторами на основі $[3 ; 7 ; 8 ; 13]$.

Вищенаведені показники можуть також розкривати підприємства малого бізнесу в разі складання нефінансової звітності.

За даними сайта United Nations Global Compact деякі українські малі підприємства (Корпорація Solar Alliance та ТОВ Автокат) уже мають досвід подання звіту про прогрес, а деякі (European Profiles SA Україна, TOB Viteo, TOB UCG та інші) підписали листи-зобов'язання про приєднання до Глобального договору, але ще не складали звіти про прогрес [12], що свідчить про наміри українських підприємств малого бізнесу розкривати нефінансову інформацію для зовнішніх користувачів.

Таким чином, розкриття нефінансової інформації для цілей управління на підприємствах малого бізнесу та зовнішніх користувачів є додатковим інформаційним джерелом для управлінського персоналу з метою планування, організації, контролю, координування, розпорядництва та мотивації, отже, управлінські рішення, що грунтуються на фінансовій та нефінансовій інформації є більш обгрунтованими, об'єктивними та якісними. Формування фінансової та нефінансової звітності для різноманітних груп користувачів (кредитори, інвестори, споживачі, місцеве населення, контрагенти) зумовлює підвищення іміджу малого підприємства та його конкурентоздатність, розширення ринків збуту товарів, робіт та послуг, зростання можливостей отримання додаткових джерел фінансування в ринкових умовах господарювання.

Висновки і пропозиції. Таким чином, на основі проведеного дослідження можна зробити такі висновки.

1. Складання нефінансової звітності на підприємствах малого бізнесу є важливим аспектом інформаційного забезпечення внутрішніх і зовнішніх користувачів, оскільки на основі фінансової і нефінансової інформації можуть прийматися більш обгрунтовані, якісні та об'єктивні управлінські рішення щодо подальшого розвитку підприємства та його діяльності. 
ФІНАНСОВІ РЕСУРСИ: ПРОБЛЕМИ ФОРМУВАННЯ ТА ВИКОРИСТАННЯ

2. Види та форми розкриття інформації в нефінансовій звітності залежать від власних вимог, інформаційних потреб користувачів та ресурсного забезпечення (фінансового, матеріального, трудового та ін.) підприємств малого бізнесу.

3. У нефінансовій звітності підприємств малого бізнесу доцільно розкривати економічну, екологічну та соціальну інформацію, зокрема пов'язану з правами людини, соціальною відповідальністю, антикорупційною діяльністю, взаємодію з місцевими громадами.

Отже, у статті обгрунтовано важливість та необхідність розкриття нефінансової інформації для підприємств малого бізнесу, що зумовлює проведення додаткових подальших досліджень у частині доцільності розробки та впровадження форм звітності нефінансового характеру для підприємств малого бізнесу в Україні.

\section{Список використаних джерел}

1. Воробей В., Журовська І. Нефінансова звітність: інструмент соціально відповідального бізнесу. Київ : ТОВ «Інжиніринг» Друк ФОП Костюченко О. М., 2010. 84 с. URL: http://www.ppv.net.ua/uploads/work_attachments/Non-Financial_Reporting_UA_pdf.

2. Гнедіна К. В., Роднев Д. В. Звіт про управління: сутність та особливості формування. Сучасні світові тенденції розвитку інформаційних технологій, економіки і права : збірник матеріалів міжнародної науково-практичної конференції ЧІІБІП МНТУ імені академіка Ю. Бугая (Чернігів, 18 квітня 2019 року). Чернігів, 2019. С. 79-82.

3. Звіт про прогрес 2018 «Нексія ДК». URL: https://s3-us-west-2.amazonaws.com/ungcproduction/attachments/cop_2019/472584/original/Communication_on_Progress_Nexia_DK_2018.pd f? 1552575196 .

4. Кальчук А. Л. Нефінансова звітність: її сутність та класифікація. Сучасні тенденції розвитку бухгалтерського обліку та оподаткування : тези виступів Міжнар. наук.-практ. конф. URL: http://eztuir.ztu.edu.ua/123456789/6247.

5. Косич А. О., Яковенко Я. Ю. Звіт про стійкий розвиток як аналітичний інструмент формування корпоративної соціальної відповідальності. Ефективна економіка. 2014. № 10. URL: http://www.economy.nayka.com.ua/?op=1\&z=3400.

6. Нефінансова інформація: чому бізнесу важливо iï використовувати URL: https://uteka.ua/ua/publication/news-14-delovye-novosti-36-nefinansovaya-informaciya-pochemubiznesu-vazhno-ee-ispolzovat.

7. Нефінансовий звіт ДП «НАЕК «ЕНЕРГОАТОМ» 2018 рік. URL: http://nfr2018.energoatom.kiev.ua.

8. Нефінансовий звіт ТОВ «АГРОТЕХСОЮЗ» 2018 p. URL: https://s3-us-west2.amazonaws.com/ungcproduction/attachments/cop_2019/472828/original/3віт_КСВ_АГРОТЕХСОЮ3_2018p.pdf?1553274529.

9. Онищенко В. Порівняння національних та міжнародних вимог до складання звіту про управління. Проблеми і перспективи економіки та управління. 2018. № 4 (16). С. 230-238.

10. Про бухгалтерський облік та фінансову звітність в Україні : Закон України від 16.07.1999 № 996-XIV. URL: https://zakon.rada.gov.ua/laws/show/996-14.

11. Про затвердження Методичних рекомендацій зі складання звіту про управління : Наказ Мінфіну України від 07.12.2018 № 982. URL: https://zakon.rada.gov.ua/rada/show/v0982201-18.

12. Проданчук М. Інтегрована звітність - інструмент управління підприємством. Бухгалтерський облік і аудит. 2014. № 2. С. 24-31.

13. Публічний звіт про результати діяльності AT «Пласке» за 2017 рік. URL: https://s3-uswest-2.amazonaws.com/ungc-

production/attachments/cop_2018/463067/original/PLASKE_REPORT_2017_UA.pdf?1525078701.

14. Сидоренко О. Звітні сегменти підприємств України: поняття та порядок визнання. Проблеми і перспективи економіки та управління. 2016. № 2 (6). С. 411-416.

15. Directive 2013/34/eu of the european parliament and of the council of 26 June 2013 on the annual financial statements, consolidated financial statements and related reports of certain types of undertakings, amending Directive 2006/43/EC of the European Parliament and of the Council and repealing Council Directives 78/660/EEC and 83/349/EEC. URL: https://eur-lex.europa.eu/legalcontent/EN/TXT/PDF/?uri=CELEX:32013L0034\&qid=1574319266253\&from=EN. 
ФІНАНСОВІ РЕСУРСИ: ПРОБЛЕМИ ФОРМУВАННЯ ТА ВИКОРИСТАННЯ

16. Directive 2014/95/eu of the european parliament and of the council of 22 October 2014 amending Directive 2013/34/EU as regards disclosure of non-financial and diversity information by certain large undertakings and groups. URL: https://eur-lex.europa.eu/legal-content/EN/TXT/PDF/ ?uri=CELEX:32014L0095\&from $=$ EN.

17. GRI sustainability reporting standards. GRI Official Website. URL: https://www.globalreporting.org/information/sustainability-reporting/Pages/gri-standards.aspx.

18. Our Participants. Oфіиійний caŭm United Nations Global Compact. URL https://www.unglobalcompact.org/what-is-gc/participants.

19. The Communication on Progress (CoP) in Brief. Oфiиiйний caŭm United Nations Global Compact. URL: https://www.unglobalcompact.org/participation/report/cop.

\section{References}

1. Vorobei, V., Zhurovska, I. (2010). Nefinansova zvitnist: instrument sotsialno vidpovidalnoho biznesu [Non-financial reporting: an instrument of socially responsible business]. Kyiv: TOV «Inzhynirynh» Druk FOP Kostiuchenko O. M. Retrieved from http://www.ppv.net.ua/uploads/ work attachments/Non-Financial Reporting UA .pdf.

2. Hnedina, K. V., Rodnev, D. V. (2019). Zvit pro upravlinnia: sutnist ta osoblyvosti formuvannia. Suchasni svitovi tendentsii rozvytku informatsiinykh tekhnolohii, ekonomiky i prava [Management report: the nature and features of the formation. Current world trends in information technology, economy and law]. Zbirnyk materialiv mizhnarodnoi naukovo-praktychnoi konferentsii ChIIBIP MNTU imeni akademika Yu. Buhaia - Current world trends in information technology, economy and law. Collection of Proceedings of the International Scientific and Practical Conference ChIIBIP MSTU named after Academician Y. Bugai (pp. 79-82). Chernihiv [in Ukrainian].

3. Zvit pro prohres 2018 «Neksiia DK» [Progress Report 2018 on Nexia DK]. Retrieved from https://s3-us-west-2.amazonaws.com/ungc-production/attachments/cop_2019/472584/original/

Communication_on_Progress_Nexia_DK_2018.pdf?1552575196.

4. Kalchuk, A. L. (2016). Nefinansova zvitnist: yii sutnist ta klasyfikatsiia [Non-financial reporting: its essence and classification]. Suchasni tendentsii rozvytku bukhhalterskoho obliku ta opodatkuvannia: tezy vystupiv Mizhnar. nauk.-prakt. konf. - Current trends in accounting and taxation: Abstracts International. Research Practice Conf. Retrieved from http://eztuir.ztu.edu.ua/123456789/6247.

5. Kosych, A. O., Yakovenko, Ya. Yu. (2014). Zvit pro stiikyi rozvytok yak analitychnyi instrument formuvannia korporatyvnoi sotsialnoi vidpovidalnosti [Report on sustainable development as an analytical tool for forming corporate social responsibility]. Efektyvna ekonomika - Efficient economy, 10. Retrieved from http://www.economy.nayka.com.ua/?op=1\&z=3400.

6. Nefinansova informatsiia: chomu biznesu vazhlyvo yii vykorystovuvaty [Non-financial information: why it is important for a business to use it]. Retrieved from https:/uteka.ua/ua/publication/ news-14-delovye-novosti-36-nefinansovaya-informaciya-pochemubiznesu-vazhno-ee-ispolzovat.

7. Nefinansovyi zvit DP «NAEK "ENERHOATOM"» 2018 rik [Non-financial report of SE «NAEK “ENERGOATOM”» 2018]. Retrieved from http://nfr2018.energoatom.kiev.ua.

8. Nefinansovyi zvit TOV «AHROTEKhSOIuZ» $2018 \mathrm{r}$ [Non-financial report of Agrotechsoyuz LLC, 2018]. Retrieved from https://s3-us-west-2.amazonaws.com/ungc-production/attachments/ cop_2019/472828/original/Zvit_KSV_AHROTEKhSOIuZ_2018r.pdf? 1553274529.

9. Onyshchenko, V. (2018). Porivniannia natsionalnykh ta mizhnarodnykh vymoh do skladannia zvitu pro upravlinnia [Comparison of national and international management report requirements]. Problemy $i$ perspektyvy ekonomiky ta upravlinnia - Problems and prospects of economy and management, 4 (16), 230-238 [in Ukrainian].

10. Pro bukhhalterskyi oblik ta finansovu zvitnist v Ukraini [On Accounting and Financial Reporting in Ukraine]. № 996-XIV (16.07.1999). URL: https://zakon.rada.gov.ua/laws/show/996-14.

11. Pro zatverdzhennia Metodychnykh rekomendatsii zi skladannia zvitu pro upravlinnia [On Approval of Methodological Recommendations for Preparation of the Management Report]. № 982 (07.12.2018). Retrieved from https://zakon.rada.gov.ua/rada/show/v0982201-18. 
ФІНАНСОВІ РЕСУРСИ: ПРОБЛЕМИ ФОРМУВАННЯ ТА ВИКОРИСТАННЯ

12. Prodanchuk, M. (2014). Intehrovana zvitnist - instrument upravlinnia pidpryiemstvom [Integrated reporting - an enterprise management tool.]. Bukhhalterskyi oblik $i$ audit-Accounting and Auditing, 2, 24-31 [in Ukrainian].

13. Publichnyi zvit pro rezultaty diialnosti AT «Plaske» za 2017 rik [Public report on the results of the activity of JSC "Plaske" for 2017]. Retrieved from https://s3-us-west-2.amazonaws.com/ungcproduction/attachments/cop 2018/463067/original/PLASKE_REPORT 2017 UA.pdf?1525078701.

14. Sydorenko, O. (2016). Zvitni sehmenty pidpryiemstv Ukrainy: poniattia ta poriadok vyznannia [Reporting segments of Ukrainian enterprises: concept and order of recognition]. Problemy $i$ perspektyvy ekonomiky ta upravlinnia - Problems and prospects of economy and management, 2 (6), 411-416 [in Ukrainian].

15. Directive 2013/34/eu of the european parliament and of the council of 26 June 2013 on the annual financial statements, consolidated financial statements and related reports of certain types of undertakings, amending Directive 2006/43/EC of the European Parliament and of the Council and repealing Council Directives 78/660/EEC and 83/349/EEC. Retrieved from https://eurlex.europa.eu/legalcontent/EN/TXT/PDF/?uri=CELEX:32013L0034\&qid=1574319266253\&from=EN.

16. Directive 2014/95/eu of the european parliament and of the council of 22 October 2014 amending Directive 2013/34/EU as regards disclosure of non-financial and diversity information by certain large undertakings and groups. Retrieved from https:/eur-lex.europa.eu/legalcontent/EN/TXT/PDF/?uri=CELEX:32014L0095\&from=EN.

17. GRI Official Website (n.d.). GRI sustainability reporting standards. Retrieved from https://www.globalreporting.org/information/sustainability-reporting/Pages/gri-standards.aspx.

18. Ofitsiinyi sait United Nations Global Compact (n.d.). Our Participants. Retrieved from https://www.unglobalcompact.org/what-is-gc/participants.

19. Ofitsiinyi sait United Nations Global Compact (n.d.). The Communication on Progress (CoP) in Brief. Retrieved from https://www.unglobalcompact.org/participation/report/cop.

Гоголь Тетяна Анатоліївна - доктор економічних наук, професор, професор кафедри бухгалтерського об-

ліку, оподаткування та аудиту, Чернігівський національний технологічний університет (вул. Шевченка, 95, м. Чернігів, 14035, Україна).

Гоголь Татьяна Анатольевна - доктор экономических наук, профессор, профессор кафедры бухгалтерско-

го учета, налогообложения и аудита, Черниговский национальный технологический университет (ул. Шевченко, 95, г. Чернигов, 14035, Украина).

Gogol Tetyana - Doctor of Economics, Professor, Professor of the Department of Accounting, Taxation and Audit, Chernihiv National University of Technology (95 Shevchenka Str., 14035 Chernihiv, Ukraine).

E-mail: tatyanagogoll@gmail.com

ORCID: https://orcid.org/0000-0002-0885-6271

ResearcherID: F-6030-2016

Колоток Вадим Олександрович - аспірант кафедри бухгалтерського обліку, оподаткування та аудиту, Чернігівський національний технологічний університет (вул. Шевченка, 95, м. Чернігів, 14035, Україна).

Колоток Вадим Александрович - аспирант кафедры бухгалтерского учета, налогообложения и аудита, Черниговский национальный технологический университет (ул. Шевченко, 95, г. Чернигов, 14035, Украина).

Kolotok Vadym -PhD student of the Department of Accounting, Taxation and Audit, Chernihiv National University

of Technology (95 Shevchenka Str., 14035 Chernihiv, Ukraine).

E-mail: kolotokvo@ukr.net

ORCID: https://orcid.org/0000-0002-1577-4944

ResearcherID: V-3184-201

Гоголь Т., Колоток В. Розкриття нефінансової інформації в звітності підприємств малого бізнесу. Проблеми і перспективи економіки та управління. 2020. № 1 (21). С. 174-182. 